\title{
Kompetensi Profesional Guru SMK Bidang Keahlian Teknik Bangunan di Medan
}

\author{
Zulkifli Matondang \\ Email: zulkiflimato@vahoo.com
}

\begin{abstract}
Abstrak. Penelitian bertujuan untuk mengetahui kompetensi profesional guru SMK bidang keahliah teknik bangunan. Sebelum pengukuran kompetensi profesional guru, dikembangkan tes yang standar. Proses pengembangan tes dilakukan dengan dua fase yaitu melalui expert jugment oleh ahli dan ujicoba empiris. Pertama, dilibatkan 20 orang ahli yang terdiri dari: doktor evalusi, dosen teknik bangunan, dan guru. Kedua, ujicoba dilakukan pada 276 orang guru bidang keahliah teknik bangunan di Medan. Validitas konstruk tes dihitung dengan analisis faktor. Hasil penelitian menunjukkan bahwa faktor yang dibentuk oleh kompetensi profesional cukup baik. Setiap indikator memiliki loading faktor diatas 0.30. Dengan metode rotasi varimax diperoleh 10 faktor yang membentuk kompetensi profesinal guru SMK. Reliabiulitas tes dihitung dengan rumus KR-20, dan diperoleh koefisien reabilitas sebesar 0,858 . Hasil perhitungan menyimpulkan bahwa tes yang dikembangkan dapat digunakan untuk mengukur kompetensi profesional guru SMK. Hasil pengukuran diperoleh kompetensi profesional guru SMK bidang keahliah teknik bangunan di Medan masuk pada kategori perlu perbaikan, sehingga perlu meningkatkan pengetahuan guru di bidangnya.
\end{abstract}

Kata kunci : kompetensi profesional, pengembangan tes, dan guru SMK.

\begin{abstract}
This study aimed to know of teacher's profesional competence at SMK (vocational scholl) in the field of building construction. Before to measure of teacher's profesional competence, developing a standard instrument. The study was conducted in two phases: a rational try-out through experts' assessment, followed by an empirical try-out. The first phase incorporated 20 experts; i.e. university lecturers of building construction. In the second phase, a competence test was administered to 276 teachers in Medan. Construct validity was examined by a factor analysis technique. The results indicated that the indicators fitted the construct; each indicator had a factor loading higher than 0.30 . Varimax rotation resulted in a decrease in the factors of competence test, compared to the previously theorized, as profesional dimension had 10 factors. The reliability of the instrument was evaluated by KR-20 formula, and the coefficient 0.858 . Therefore, it can be concluded that the instrument can be used to measure the competence of building construction teachers of SMK. The result study was teacher's profesional competence at SMK in Medan repair to improved, therefore requar to add of teacher's knowladge in their field .
\end{abstract}

Key words : profesional competence, developing test, and SMK teacher.

\section{Pendahuluan}

Secara makro mutu pendidikan di Indonesia saat ini dianggap relatif rendah. Tahun 2000 dan 2002 mutu pendidikan di Indonesia di bawah Singapura, Thailand, dan Filipina; bahkan pernah di bawah Vietnam (studi UNDP 2000 dan 2002 dalam Prayitno, 2005:2). Hal ini sangat ironis mengingat klaim berbagai pihak tentang gencarnya upaya pengembangan pendidikan pada dua dekade terakhir abad ke-20 yang lalu. Bahkan pernah dikatakan "tidak ada bidang kegiatan lain yang mendapat perhatian sebanyak yang diarahkan kepada bidang pendidikan". Namun, besarnya perhatian itu tidak serta merta membuahkan keberhasilan yang tinggi dan mengesankan (Prayitno, 2005: 4).

Salah satu aspek yang diduga penyebab rendahnya mutu pendidikan Indonesia adalah akibat guru, kerena guru merupakan agen dan pengelola pembelajaran di kelas. Data menunjukkan bahwa guru yang mengajar pada sekolah di Indonesia relatif banyak yang kurang kompeten, dan jumlah guru masih kurang dibandingkan dengan jumlah siswa. Berdasarkan 
Pusat Data dan Informasi Pendidikan Balitbang Depdiknas dikemukakan bahwa kualifikasi pendidikan guru di Indonesia yang kurang layak yaitu masing-masing pada tingkat: SD sebesar 49,3\%, SMP sebesar 35,9\%, SMA sebesar 32,9\% dan SMK sebesar 43,3\%. Data ini memperlihatkan bahwa kualifikasi guru berdasarkan pendidikan relatif rendah, karena masih banyak proporsi yang kurang layak.

Bila diperhatikan lebih mendetail tentang data tentang kualifikasi tingkat pendidikan guru SMK di Indonesia menunjukkan bahwa yang memiliki pendidikan setara D-I sebesar 3,54\%, setara DII sebesar $1,79 \%$, setara D-III sebesar 30,18\%, setara S-I sebesar $64,16 \%$ dan diatas S-I sebesar 0,33\% (Depdiknas, 2002 : 31). Lebih lanjut data menunjukkan bahwa jumlah guru SMK masih kurang sebanyak 82.859 orang masing masing sebesar 9.008 orang pada SMK Negeri dan 73.851 orang pada SMK Swasta. Berdasarkan data guru tersebut, khususnya pada SMK maka perlu suatu standar untuk memperbaiki mutu pendidikan. Salah satu aspek penting yang perlu diperhatikan terhadap guru dan calon guru di Indonesia, selain kualifikasi pendidikan juga kompetensinya sebagai seorang guru.

Dalam pengembangan guru, dikenal istilah guru sebagai tenaga fungsional dan guru sebagai tenaga profesional. Kedua kebijakan tersebut pada hakekatnya ditujukan untuk meningkatkan kompetensi dan kesejahteraan guru, yang keduanya merupakan satu kesatuan yang tidak dapat dipisahkan. Oleh karena itu, implementasi kebijakan harus senantiasa mengandung keterkaitan antara kompetensi dan kesejahteraan.

Salah satu jenjang pendidikan adalah Pendidikan Menengah. Pendidikan menengah merupakan lanjutan dari pendidikan dasar dan salah satu bentuknya yaitu Sekolah Menengah Kejuruan (SMK). Untuk meningkatkan mutu pendidikan pada jenjang SMK, maka perlu usaha yang sadar untuk meningkatkan mutu penyelenggara pendidikan SMK yang salah satunya adalah mutu tenaga pengajar (guru). Dalam meningkatkan kompetensi harus dipahami apa dan bagaimana karakteristik kerja guru. Kebijakan peningkatan kompetensi guru dijabarkan dalam program kegiatan yang serasi dengan karakteristik kerja guru. Tiga karakteristik kerja guru yang perlu mendapat perhatian, yaitu: Pertama, waktu kerja guru habis di ruang kelas sehingga interaksi antar guru rendah. Kedua, kerja guru dari waktu ke waktu dihadapkan pada keharusan bekerja secara individual dan mengambil keputusan yang bersifat non-kolaboratif. Ketiga, kerja guru tidak pernah mendapat umpan balik dari siswa, kolega guru atau kepala sekolah. Guru tidak pernah mengetahui kelemahan dan keunggulannya, sehingga guru tidak pernah memahami apa yang harus dilakukan untuk memperbaiki kinerjanya.

Sejalan dengan karakteristik tersebut, maka pengembangan jenjang promosi karier guru harus senantiasa bertumpu pada hakekat kerja guru. Tugas utama guru adalah mengajar dan melangsungkan proses pembelajaran. Pembinaan kualitas profesional guru yang terkandung dalam kebijakan jenjang jabatan fungsional, mesti bertumpu pada kemampuan melaksanakan pembelajaran tersebut.

Mengelola pembelajaran memerlukan dua bekal pokok, yaitu bekal tentang materi ajar dan pengetahuan tentang subjek yang diajar (siswa). Namun, penguasaan pengetahuan tersebut belum cukup, masih diperlukan kemampuan yang mencakup: a) kemampuan untuk menilai dan mengambil keputusan dalam proses pembelajaran, b) kemampuan untuk melakukan improvisasi sesuai dengan kondisi yang ada, c) kemampuan untuk bekerja sama. Kemudian dalam pelaksanaan proses pembelajaran diperlukan adanya komitmen guru terhadap siswa dan kebutuhan belajar siswa.

Kebijakan dan program peningkatan kualitas profesional guru harus dipahami oleh stakeholder pendidikan, khususnya oleh guru itu sendiri. Sejalan dengan kebijakan peningkatan kompetensi dan jabatan, guru harus menfokuskan pada peningkatan kualitas proses pembelajaran. Menurut Sukamto, penilaian dan sertifikasi kompetensi guru untuk pengembangan karir dalam jabatan meliputi: a) kompetensi kemampuan bidang studi (guru SMK merupakan guru bidang studi majemuk "multiple subject"), b) kompetensi pemahaman karakteristik siswa, c) kompetensi pembelajaran yang mendidik, dan d) kompetensi pengembangan profesi dan kepribadian pendidik (Sukamto, 2004). 
Kemampuan pemahaman bidang studi merupakan salah satu kompetensi profesional seorang guru. Pemahaman materi bidang studi bagi seorang guru mutlak diperlukan, karena merupakan konten (isi) yang akan disampaikan dalam kegiatan pembelajaran. Penelitian ini ingin mengetahui pemahaman guru terhadap materi bidang studinya yaitu teknik bangunan. Penelitian sangat penting dilakukan untuk mengetahui kompetensi profesional para guru. Tes kompetensi profesional dapat digunakan sebagai salah satu alat ukur (instrumen) dalam sertifikasi profesi guru.

Sertifikasi kompetensi profesi menjadi penting secara jurisdiksi. Jurisdiksi profesi secara langsung berhubungan dengan sistem ilmu pengetahuan yang mendasarinya yang diakui dan didukung dengan pendidikan/pelatihan sebagai dasar terbentuknya profesi. Dengan sertifikasi profesi maka keandalan kinerja dari jabatan yang dipegang oleh seseorang akan dijamin, paling tidak pada tingkat kualifikasi kompetensi minimal. Dalam tatanan masyarakat global yang semakin terbuka dan kompetitif, tuntutan akan kebutuhan sertifikasi profesi semakin besar. Sertifikasi guru sebagai upaya peningkatan mutu guru dibarengi dengan peningkatan kesejahteraan guru. Melalui sertifikasi diharapkan dapat meningkatkan mutu pembelajaran dan mutu pendidikan di Indonesia secara berkelanjutan.

Dalam rangka pengukuran kompetensi profesional guru perlu dilakukan suatu penelitian. Penelitian ini penting dilakukan agar dapat mengetahui kompetensi profesional guru SMK bidang keahlian teknik bangunan. Sebelum mengukur kompetensi guru, terlebih dahulu dikembangkan suatu tes yang standar (memenuhi validitas dan reliabilitas) sehingga dapat digunakan untuk mengukur kompetensi profesional guru. Berdasarkan uraian di atas, maka rumusan masalah dalam penelitian ini yaitu: 1) bagaimanakah kompetensi profesional guru SMK bidang keahlian teknik bangunan di Medan?, 2) bagaimanakah kualitas instrumen (tes) yang dikembangkan untuk mengukur kompetensi profesional guru SMK bidang keahlian teknik bangunan?.

\section{Kajian Literatur Kompetensi Profesional}

Berdasarkan kamus Indonesia-Inggiris, kompetensi berasal dari bahasa Inggiris yaitu competence (John M.E dan Hassan Shadily, 1997:304). Maknanya sama dengan being competent, sedangkan competent sama artinya dengan having ability, power, authoority, skill, knowledge, attitude dan sebagainya. Dengan demikian kompetensi adalah kemampuan, kecakapan, keterampilan dan pengetahuan seseorang dibidang tertentu. Jadi kata kompetensi diartikan sebagai kecakapan yang memadai untuk melakukan suatu tugas atau suatu keterampilan dan kecakapan yang disyaratkan.

Elliot (2005:5) mengemukakan bahwa kompetensi dapat didefinisikan sebagai suatu kondisi atau kualitas dari keefektifan, kemampuan, atau kesuksesan. Depdiknas (2002:1) merumuskan bahwa bahwa kompetensi adalah suatu pengetahuan, keterampilan dan nilai-nilai dasar yang direfleksikan dalam kebiasaan berpikir dan bertindak. Selain itu ada juga yang memberi makna kompetensi hampir sama dengan keterampilan hidup atau "life skills". Kompetensi atau keterampilan hidup dinyatakan dalam bentuk kinerja atau performansi yang dapat diukur.

Pengembangan kompetensi merupakan suatu proses konsolidasi dalam memahirkan seperangkat keterampilan yang dibutuhkan untuk mencapai domain kehidupan (Sternberg, 2005:15). Kompetensi guru dinilai penting sebagai alat seleksi dalam penerimaan calon guru, yang dapat dijadikan pedoman dalam rangka pembinaan dan pengembangan tenaga guru.

Kompetensi profesional merupakan suatu kemampuan sesuai dengan keahliannya. Seorang guru harus harus menyampaikan sesuatu (sesuai keahliannya) kepada peserta didik dalam rangka menjalankan tugas dan profesinya. Kanfel (2005:337) mengemukakan bahwa kompetensi di tempat kerja merupakan perpaduan antara performans maksimum dan tipikal perilaku seseorang. Seorang guru harus memiliki kompetensi profesional dalam bidang keahliannya.

Berdasarkan uraian di atas dapat dikemukan bahwa kompetensi profesional guru adalah suatu performansi (kemampuan) yang dimiliki seorang guru meliputi aspek pengetahuan, keterampilan, 
proses berpikir, penyesuaian diri, sikap dan nilainilai yang dianut dalam melaksanakan profesi sebagai guru. Dalam melaksanakan kegiatan, seorang guru berpikir dan bertindak secara konsisten dan terus menerus sesuai dengan kompetensinya.

\section{Standar Kompetensi Guru SMK Bidang Keahlian Teknik Bangunan}

Secara umum seorang guru harus memenuhi dua kategori, yaitu memiliki capability dan loyality (Hadiyanto, 2004:12). Capability, yakni guru harus memiliki kemampuan dalam bidang ilmu yang diajarkannya, memiliki kemampuan teoritik tentang mengajar yang baik; mulai perencanaan, implementasi sampai evaluasi. Loyality keguruan, yakni loyal terhadap tugas-tugas keguruan, tidak semata di dalam kelas dan di masyarakat.

Guru adalah orang yang bertanggung jawab mencerdaskan kehidupan anak didik. Untuk itu seorang guru dengan penuh dedikasi dan loyalitas berusaha membimbing dan membina akan didik agar menjadi orang berguna di masa mendatang. Guru memberikan sejumlah norma kepada anak didik agar mereka tahu mana yang susila dan asusila. Anak didik lebih banyak menilai apa yang ditampilkan guru di kelas, di sekolah dan di masyarakat. Untuk itu seorang guru harus memiliki sifat: 1) Menerima dan mematuhi norma, nilai-nilai kemanusiaan; 2) memikul tugas mendidik dengan bebas, berani dan gembira; 3) sadar akan nilainilai yang berkaitan dengan perbuatannya; 4) menghargai orang lain; 5) bijaksana dan hati-hati; dan 6) taqwa terhadap Tuhan Yang Maha Esa (Syaiful B. Djamarah, 2005:36).

Interstate New Teacher Assessment and Support Consorcium (INTASC) menjelaskan bahwa seorang guru harus memiliki pemahaman tentang: bidang ilmu, pengembangan potensi anak, berbagai strategi pembelajaran, pengeIolaan kelas, kemampuan berkomunikasi, perencanaan pembelajaran, penilaian hasil belajar, komitmen, dan menjalin hubungan dengan berbagai pihak.

Bagi seorang guru SMK bidang keahlian teknik bangunan, salah satunya standar kompetensinya yaitu memiliki pengetahuan dan pemahaman dasar di bidang teknik bangunan. Berdasarkan kurikulum SMK, beberapa kompetensi yang dikuasai oleh guru bidang keahlian teknik bangunan meliputi: a) Ilmu bahan, dasar perencanaan dan gambar teknik bangunan; b) dasar-dasar mekanika teknik; dan c) dasar-dasar ilmu konstruksi seperti: konstruksi kayu, konstruksi beton, konstruksi baja, dan konstruksi bangunan.

Dari uraian di atas maka standar kompetensi dari seorang guru bidang keahlian teknik bangunan meliputi suatu pengetahuan dan kemampuan dalam hal : a) penguasaan bidang studi (materi) pembelajaran secara luas dan mendalam yang memungkinkannya membimbing peserta didik memenuhi kompetensi yang ditetapkan dalam standar nasional pendidikan; dan b) memilih dan mengembangkan kurikulum dan atau silabus sesuai standar kompetensi dan kompetensi dasar mata pelajaran yang diampu.

Berdasarkan standar kompetensi tersebut, maka kompetensi guru bidang keahlian teknik bangunan dapat dikategorikan: a) memahami standar kompetensi dan kompetensi dasar bidang keahlian teknik bangunan; b) mampu memilih dan mengembangkan materi pelajaran; c) menguasai materi, struktur, dan konsep pola pikir keilmuan yang mendukung bidang keahlian teknik bangunan; d) menguasai metode untuk melakukan pengembangan ilmu dan telaah kritis terkait dengan bidang keahlian teknik bangunan; e) kreatif dan inovatif dalam penerapan bidang ilmu yang terkait dengan bidang keahlian teknik bangunan; f) mampu mengembangkan kurikulum dan silabus yang terkait dengan bidang keahlian teknik bangunan, mampu melakukan tindakan reflektif untuk peningkatan kualitas pembelajaran; g) mampu berkomunikasi dengan komunitas profesi sendiri dan profesi lain secara lisan maupun tulisan; dan h) mampu memanfaatkan teknologi informasi dan komunikasi untuk kepentingan pembelajaran, berkomunikasi dan mengembangkan diri sebagai seorang guru.

\section{Teori Pengembangan Instrumen}

Secara umum instrumen adalah suatu alat yang digunakan untuk mengukur fenomena alam maupun fenomena sosial yang diamati. Instrumen merupakan alat bantu bagi peneliti dalam mengumpulkan data. Djaali dan Puji Muljono (2004:7) mengemukakan dalam bidang penelitian instrumen diartikan sebagai alat untuk me- 
ngumpulkan data mengenai variabel-variabel penelitian. Alat ukur (instrumen) yang dibuat/ disusun untuk melakukan pengukuran, sebelum digunakan harus terlebih dahulu dikalibrasi atau divalidasi (Scriven, 1981:95). Jadi suatu instrumen dapat digunakan untuk mengukur fenomena sosial atau fenomena alam yang akan diamati, namun terlebih dahulu dilakukan kalibrasi sebelum dipergunakan.

Pada dasarnya instrumen dibagi dua, yaitu instrumen yang berbentuk tes dan instrumen yang non tes (Arikunto, 2002:144). Tes merupakan prosedur sistematis untuk melakukan pengamatan terhadap perilaku seseorang dan mendiskripsikan perilaku tersebut dengan bantuan skala angka atau suatu sistem penggolongan. Indikator perilaku yang diungkap oleh instrumen tes bersifat kinerja maksimal (maximum performance) karena suatu tes dirancang untuk mengungkapkan kemampuan individu secara maksimal. Yang termasuk dalam kelompok tes adalah tes prestasi belajar, tes inteligensi, tes bakat, atau tes kemampuan akademik.

Sementara itu, indikator perilaku yang diungkap oleh instrumen yang berbentuk non tes bersifat kinerja tipikal (typical performance). Instrumen ini dirancang dengan menggunakan stimulus yang tidak mempunyai standar sehingga individu dapat membuat penafsirannya sendiri terhadap stimulus tersebut dan meresponnya sesuai dengan aspek afektif dalam dirinya saat itu (Cronbach, 1984:32). Berdasarkan uraian di atas, maka dapat dikemukakan bahwa hakikat instrumen adalah sebagai alat ukur yang memiliki kualitas validitas dan reliabilitas yang baik, dan digunakan untuk mengumpulkan data dalam suatu penelitian.

Untuk mengetahui kompetensi profesional guru SMK diperlukan suatu instrumen untuk mengukurnya. Lebih lanjut instrumen yang digunakan untuk mengukur kompetensi guru harus memiliki kesahihan (validity) dan keterandalan (reliability) yang memadai. Para ahli instrumen mengemukakan bahwa instrumen yang sahih dan valid dinamakan instrumen baku, karena prosesnya melalui kegiatan pembakuan dalam suatu penelitian.

Menurut Ebel (1991:30), instrumen baku adalah instrumen yang: 1 ) disusun oleh para pakar penyusun instrumen dan dikalibrasi, dianalisis dan diperbaiki; 2) mempunyai petunjuk pelaksanaan dan penyekoran yang jelas; dan 3) memiliki acuan norma untuk menginterpretasi suatu sekor. Instrumen baku adalah instrumen yang dikembangkan secara empiris melalui beberapa pengujian. Instrumen baku memiliki beberapa pembatasan, baik yang menyangkut isi, penyelenggaraan pengukuran maupun hasil pengukuran, Pembakuan suatu alat ukur/ instrumen menyangkut beberapa persoalan. Gronlund (1990:319) menjelaskan ciri-ciri instrumen baku, yaitu: 1) butir-butir secara teknis berkualitas; 2) administrasi dan penilaian jelas; 3) adanya norma dan penafsiran yang pasti; dan 4) adanya petunjuk dan perlengkapan instrumen lainnya. Secara umum terdapat dua hal yang penting dalam pembakuan instrumen, yaitu isi dan pengadministrasiannya. Menurut Aiken (1994:74) selain melihat validitas dan reliabilitas, pembakuan instrumen juga menyangkut segi administrasi instrumen dan pensekorannya. Berdasarkan teoriteori di atas, maka dapat dikatakan bahwa instrumen baku adalah instrumen yang diperoleh dari proses pengembangan instrumen melalui prosedur teoritis dan empiris dengan beberapa pengujian.

\section{Analisis Faktor}

Menurut Litwin (1995:47), metode analisis faktor dilakukan dengan bantuan komputer untuk menilai apakah butir-butir yang beragam dalam survei memiliki kebersamaan dalam suatu skala tertentu. Jadi analisis faktor bertujuan untuk menganalisis sejumlah variabel dari sejumlah pengukuran atau pengamatan yang didasarkan pada teori dan kenyataan sebenarnya, serta menganalisis interkorelasi (hubungan) antar variabel tersebut. Analisis faktor pada dasarnya digunakan untuk mereduksi data, yaitu proses menjelaskan sejumlah variabel menjadi lebih sedikit dengan bantuan program komputer.

Ada dua pendekatan dalam analisis faktor yaitu: a) Pendekatan eksploratori (exploratory factor analysis) dan b) pendekatan konfirmatori (confirmatory factor analysis) (Tabachnick, 1989:599). Analisis faktor dapat digunakan untuk menguji hipotesis mengenai eksistensi konstruk (confirmatory analysis) atau bila tidak ada 
hipotesis yang dipersoalkan untuk mencari konstruk dalam kelompok variabel (exploratory analysis). Melalui pendekatan konfirmatori dapat diperoleh kesesuaian (goodness of fit) yang signifikan dan dapat digunakan untuk mengestimasi parameter populasi melalui sampel statistik. Secara umum uji kesesuaian (goodness of fit test) adalah uji $\mathrm{c}^{2}$. Karena pengembangan instrumen kompetensi guru terkait dengan banyak indikator perilaku empirik, maka untuk menentukan validitas konstruk penelitian ini digunakan uji analisis dengan teknik analisis faktor.

Reliabilitas merupakan indeks yang menunjukkan sejauh mana suatu alat ukur dapat dipercaya atau diandalkan. Bila suatu alat ukur dipakai berulang kali untuk mengukur gejala yang sama dan diperoleh hasil yang relatif stabil atau konsisten, maka instrumen tersebut terpercaya. Jadi reliabilitas adalah konsistensi suatu alat ukur untuk mengukur suatu objek (karakteristik) yang hendak diukur. Makin tinggi koefisien reliabilitas suatu instrumen, maka kemungkinan kesalahan yang terjadi semakin kecil. Menurut Litwin (1995:31), koefisien reliabilitas pada taraf 0,70 atau lebih biasanya dapat diterima sebagai reliabilitas yang baik.

Dalam penelitian ini, analisis faktor digunakan untuk mereduksi faktor dan menguji konstruk atau dimensi kompetensi profesional dari guru SMK bidang keahlian teknik bangunan. Pendekatan yang dilakukan adalah konfirmatori (confirmatory factor analysis)

\section{Metodologi Penelitian Pembakuan Instrumen}

Tes kompetensi profesional dikembangkan atas 9 sub dimensi (kompetensi inti guru). Setiap sub dimensi terdiri dari beberapa indikator. Butir instrumen disusun berdasarkan setiap indikator, sehingga butir yang ditulis dapat mengukur indikator yang telah ditetapkan.

Metode pengembangan instrumen yang digunakan dalam tulisan ini dibagi menjadi tiga tahap, yaitu: Pertama, pengembangan kisi dan butir-butir instrumen; Kedua, ujicoba validitas teoritis melalui panel pakar (expert judgement); Ketiga, pengambilan data untuk menguji validitas konstruk dan reliabilitas secara empiris.

Adapun langkah-langkah yang dilakukan dalam pembakuan instrumen penilaian kompetensi profesional guru diuraikan sebagai berikut: 1) Pengembangan definisi konseptual, operasional dan kisi-kisi kompetensi profesional guru bidang keahlian teknik bangunan; 2) Penyusunan butir pertanyaan untuk kompetensi profesional berdasarkan indikator; 3) Konfirmasi keterbacaan setiap butir instrumen kepada ahli; 4) Ujicoba kepada pakar (ahli) sebagai expert judgement untuk penyeleksian butir; dan 5) Analisis data uji coba panelis, serta perbaikan dari berbagai masukan para pakar; 6) Ujicoba bagi guru untuk mengetahui tingkat kesukaran, daya beda butir, validitas dan reliabilitas instrumen; 7) Merevisi instrumen berdasarkan data ujicoba dan keterbacaan setiap butir instrumen; 8) Melakukan ujicoba untuk menguji jumlah faktor/indikator dari kompetensi profesional guru; 9) Menghitung validitas dan reliabilitas instrumen yang dikembangkan; 10) Penyempurnaan perangkat tes kompetensi; 11) Pengadministrasian tes kompetensi profesional guru SMK bidang keahlian teknik bangunan; dan 12) Mengukur kompetensi profesional guru bidang keahlian teknik bangunan.

\section{Tempat dan Waktu Penelitian}

Penelitian ini dilakukan pada SMK bidang keahlian teknik bangunan dengan melibatkan para guru. Penelitian ini mulai tahap: pengembangan tes kompetensi profesional guru, pengujian rasional (expert judgement) diberikan pada 20 orang pakar, pengujian empiris pertama dilakukan pada 30 orang guru dan pengujian empiris kedua dilakukan pada 276 orang guru SMK bidang keahlian teknik bangunan. Pelaksanaan penelitian dilakukan mulai bulan Juli 2006 s.d Juli 2007 yang berlokasi di Medan.

\section{Ujicoba Instrumen}

Salah satu persyaratan yang harus dipenuhi oleh instrumen (alat ukur) adalah validitas. Validitas alat ukur berkaitan dengan sejauhmana alat ukur mampu mengukur apa yang seharusnya diukur. Menurut Gable (1986:72), validitas adalah tingkat kecocokan alat ukur (butir) untuk mengukur apa yang seharusnya diukur, Kesahihan tidak sekedar mengukur apa yang seharusnya diukur, namun juga mengandung pengertian sejauh-mana informasi yang diperoleh dari pengukuran dapat 
diinterpretasikan sebagai tingkah laku atau karakteristik yang akan diukur. Uji validitas butir tes kompetensi profesional dilakukan dengan rumus point biserial.

Reliabilitas (reliabity) adalah kekonsistenan pengukuran yang dihasilkan atau konsistensi sekor yang dihasilkan. Bila suatu instrumen dipakai berulang-ulang untuk mengukur gejala yang sama dan hasil yang diperoleh relatif stabil atau konsisten, maka instrumen tersebut terpercaya. Wiersma dalam Azwar (2003) menyatakan reliabilitas adalah konsistensi suatu instrumen mengukur sesuatu yang hendak diukur. Tinggi rendahnya reliabilitas ditunjukkan oleh suatu angka yang disebut koefisien reliabilitas. Makin tinggi koefisien reliabilitas suatu instrumen, maka kemungkinan kesalahan yang terjadi akan semakin kecil. Uji reliabilitas tes kompetensi profesional dilakukan dengan rumus KR-20. Uji empiris tahap kedua dilakukan dengan analisis faktor, untuk menguji konstruk/konten dari kompetensi profesional guru.

\section{Hasil Penelitian dan Pembahasan Tahap Pengembangan}

Tahap ini dilakukan diskusi panel yang melibatkan para guru bidang keahlian teknik bangunan dan mahasiswa S-3 program studi PEP UNJ. Tahap ini dibahas tentang perangkat tes kompetensi profesional guru SMK, dan petunjuk pengisiannya. Hasil dari tahap diskusi panel ini adalah definisi konseptual, definisi operasional dan kisi-kisi perangkat tes kompetensi profesional guru SMK bidang keahlian teknik bangunan.

\section{Ujicoba Secara Rasional oleh Pakar}

Penilaian pakar dilakukan untuk mengetahui validitas isi tes. Selain itu dapat pula diketahui reliabilitas dan kelayakan tes yang dikembangkan. Untuk melihat kelayakan perangkat tes, para pakar diminta mencermati kompetensi inti dan indikator yang telah tersusun dalam kisi-kisi.

Berdasarkan kompetensi profesional yang diujikan, para pakar mencermati kesesuaian indikator dengan kompetensi tersebut. Penilaian pakar tentang kesesuaian menggunakan skala thurstone (skor 1 - 9). Hasil uji reliabilitas interrater tes kompetensi profesional guru didapat minimal 0,803 . Nilai ini lebih besar dari
0,700 , sehingga dapat dikategorikan instrumen yang cukup reliabel. Selain itu, para pakar memberikan beberapa masukan guna penyempurnaan perangkat tes kompetensi antara lain penjelasan agar lebih operasional tentang kompetensi profesional guru.

\section{Ujicoba Empiris Tahap Pertama}

Ujicoba dilakukan pada guru SMKN 1 PST Kabupaten Deliserdang sebanyak 30 orang. Hasil analisis ujicoba empiris pertama dengan menggunakan rumus point biserial didapat sebanyak 17 butir dari 70 butir yang kurang memenuhi syarat validitas butir. Adapun nomor butir yang rendah validitasnya adalah: 5, 9, 12, $13,17,19,22,24,25,26,28,34,40,41,49,54$, dan 61 . Hasil perhitungan menggunakan rumus KR-20, diperoleh koefisien reliabilitas 0,963 lebih besar dari 0,70. Hasil perhitungan uji tingkat kesukaran butir diperoleh sebanyak 1 butir masuk kategori mudah, 56 butir masuk kategori sedang dan 13 butir masuk kategori sukar. Hasil perhitungan uji daya beda butir diperoleh kategori kurang baik sebanyak 35 butir, 14 butir masuk kategori baik dan 31 butir masuk kategori sangat baik.

\section{Ujicoba Empiris Tahap Kedua}

Hasil analisis data kompetensi profesional dengan analisis faktor, diperoleh nilai KMO sebesar 0,780, seperti terlihat pada tabel berikut:

Tabel 1. KMO dan Barlett's Test

\begin{tabular}{|c|c|c|c|}
\hline KMO & $\begin{array}{c}\text { Bartlett's Test } \\
\text { Sphericity }\end{array}$ & Df & Signifikansi \\
\hline 0,780 & 12737,796 & 1378 & 0,000 \\
\hline
\end{tabular}

Banyak faktor ditetapkan sama dengan jumlah faktor yang mempunyai variansi (eigen value) lebih besar dari 1,0. Keseluruhan faktor yang memiliki variansi lebih dari 1,0 harus mengukur minimal $70,78 \%$ dari variansi total. Muatan faktor yang tetap dipertahankan adalah di atas 0,3. Hal ini sesuai dengan aturan bahwa muatan faktor yang lebih dari 0,3 cenderung signifikan, dan kurang dari 0,3 tidak dapat memberikan kontribusi yang signifikan terhadap suatu faktor. 
Hasil analisis faktor menunjukkan bahwa tes kompetensi profesional guru SMK memiliki sebaran butir tes setelah dirotasi seperti pada Tabel 2.

Tabel 2. Sebaran Butir Tes Kompetensi Profesional Setelah Rotasi

\begin{tabular}{|c|c|c|}
\hline Faktor & Sebaran Butir & Nama Faktor \\
\hline Faktor 1 & $\begin{array}{l}1,2,5,6,7,8, \\
10,12,17,23, \\
27,31,32,36, \\
41,44,45,51, \\
53\end{array}$ & $\begin{array}{l}\text { Memahami } \\
\text { kompetensi } \\
\text { lulusan }\end{array}$ \\
\hline Faktor 2 & $35,37,42,48$ & $\begin{array}{l}\text { Memilih materi } \\
\text { pembelajaran }\end{array}$ \\
\hline Faktor 3 & $\begin{array}{l}33,39,40,47, \\
50\end{array}$ & $\begin{array}{l}\text { Menguasai materi } \\
\text { pembelajaran }\end{array}$ \\
\hline Faktor 4 & $3,4,13,16,52$ & $\begin{array}{l}\text { Menguasai pengem } \\
\text { bangan ilmu }\end{array}$ \\
\hline Faktor 5 & $28,29,43$ & Kreatif dan inovatif \\
\hline Faktor 6 & $\begin{array}{l}19,20,21,25, \\
26\end{array}$ & $\begin{array}{l}\text { Memahami pengem } \\
\text { bangan kurikulum }\end{array}$ \\
\hline Faktor 7 & $14,18,46$ & $\begin{array}{l}\text { Memahami } \\
\text { pemilihan materi }\end{array}$ \\
\hline Faktor 8 & $\begin{array}{l}9,15,22,24, \\
49\end{array}$ & $\begin{array}{l}\text { Peningkatan kuali } \\
\text { tas pembelajaran }\end{array}$ \\
\hline Faktor 9 & 30,34 & $\begin{array}{l}\text { Berkomunikasi } \\
\text { dengan rekan } \\
\text { seprofesi }\end{array}$ \\
\hline Faktor 10 & 11,38 & $\begin{array}{l}\text { Memanfaatkan } \\
\text { teknologi informasi }\end{array}$ \\
\hline
\end{tabular}

Tampilan Component Plot in Ratated Space dalam bentuk grafik dapat dilihat pada Gambar 1 berikut:

Component Plot in Rotated Space

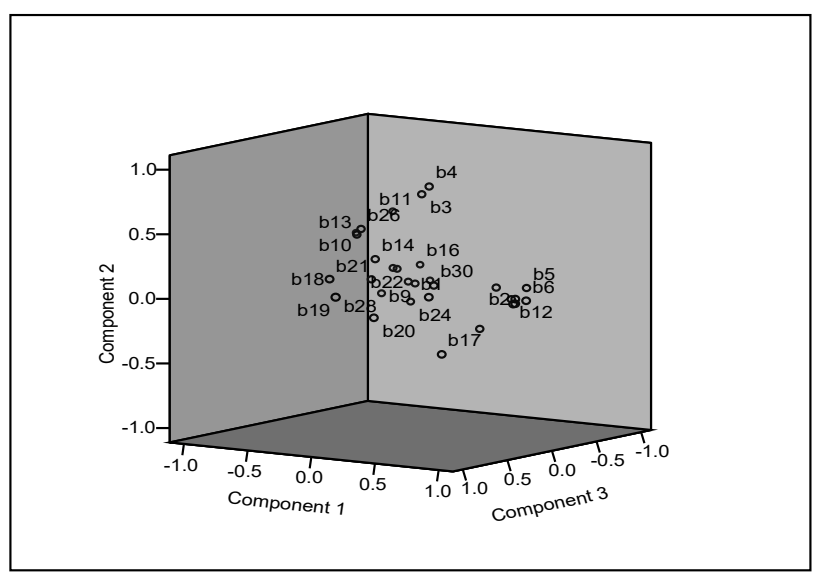

Gambar 1. Component Plot in Ratated Space Tes Kompetensi Profesional
Hasil perhitungan dengan analisis faktor menunjukkan tidak terdapat butir yang nilai AIC MSA kecil dari 0,50, sehingga tidak ada butir yang gugur. Analisis validitas konstruk melalui analisis faktor menghasilkan 10 faktor yang memiliki eigenvalue lebih dari 1,00. Total variance explained dari 10 faktor yaitu sebesar $70,78 \%$. Total variance explained dalam bentuk grafik ditunjukkan pada diagram scree (scree plot) pada gambar berikut.

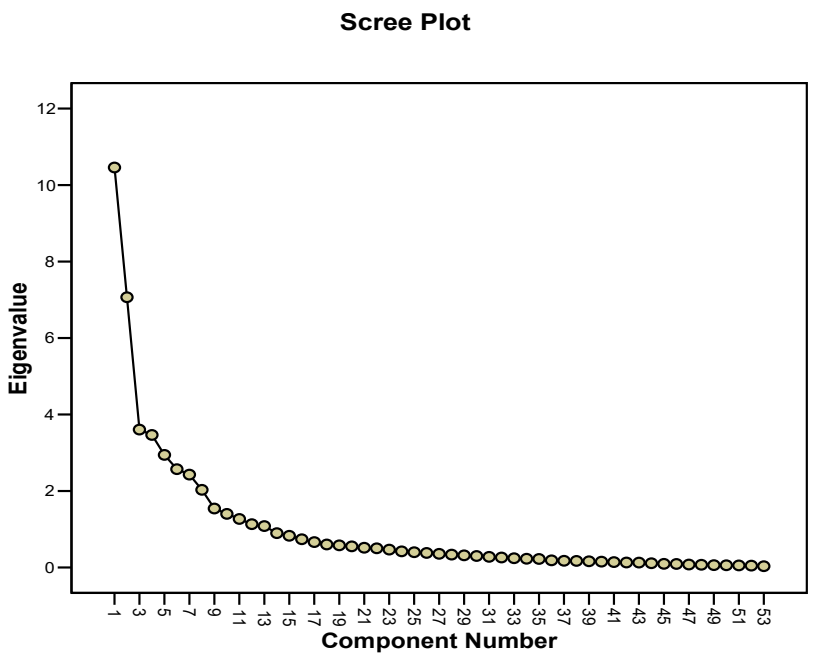

Gambar 2. Scree Plot dari Total Varians Explained Tes Kompetensi Profesional

Pendekatan konfirmatori yang dilakukan melalui komputasi dengan metode maximum likelihood, untuk menguji apakah estimasi faktor yang terbentuk berdistribusi normal. Kesesuaian (goodness of fit test) dihitung dengan rumus chikuadrat. Hasil perhitungan diperoleh indeks sebesar 373,123 dengan derajat bebas 190 dan probabilitas 0,000 . Hasil perhitungan seperti pada Tabel 3.

Tabel 3. Goodness of fit Test Kompetensi Profesional

\begin{tabular}{|l|c|c|}
\hline Chi-Square & Db & Signifikansi \\
\hline 373,123 & 190 & 0,000 \\
\hline
\end{tabular}

\section{Kompetensi Profesional Guru SMK}

Berdasarkan hasil analisis data kompetensi profesional guru bidang keahlian teknik bangunan diperoleh nilai rata-rata (mean) 51,74 dengan simpangan baku 16,56. Nilai median 49,06 dan 
nilai modus 49,06. Hasil pengolahan data kompetensi profesional dituangkan ke dalam daftar berikut.
Hasil analisis tes kompetensi profesional terbentuk 10 faktor dengan total varians sebesar 70,776 \%. Hal tersebut telah melebihi standar

Tabel 4. Distribusi Frekuensi Kompetensi Profesional

\begin{tabular}{|c|c|c|c|c|c|}
\hline No & $\begin{array}{c}\text { Rentang } \\
\text { Skor }\end{array}$ & $\begin{array}{c}\text { Frekuensi } \\
\text { Absolut }\end{array}$ & $\begin{array}{c}\text { Frekuensi } \\
\text { Relative (\%) }\end{array}$ & $\begin{array}{c}\text { Frekuensi } \\
\text { Kumulatif }\end{array}$ & $\begin{array}{c}\text { Frekuensi } \\
\text { Kumulatif (\%) }\end{array}$ \\
\hline 1 & $<$ sama 50 & 149 & 53.99 & 149 & 53.99 \\
\hline 2 & $51-60$ & 33 & 11.96 & 182 & 65.94 \\
\hline 3 & $61-70$ & 48 & 17.39 & 230 & 83.33 \\
\hline 4 & $71-80$ & 31 & 11.23 & 261 & 94.57 \\
\hline 5 & $>80$ & 15 & 5.43 & 276 & 100.00 \\
\hline & Jumlah & 276 & 100.00 & - & - \\
\hline
\end{tabular}

\section{Pembahasan}

Secara umum perangkat tes kompetensi profesional guru dapat digunakan untuk menilai kompetensi guru bidang keahlian teknik bangunan. Dalam proses pengembangan tes, rancangan awal perangkat tes mengalami cukup banyak perbaikan, mulai dari hasil ujicoba rasional dan ujicoba empiris. Pengembangan tes mencakup isi, fokus dan format penyusunan kisi-kisi instrumen dan butir-butir indikator. Selain itu perbaikan dilakukan untuk kesesuaian isi pada setiap indikator dan dimensi kompetensi. Kalimat petunjuk umum dinilai dan direvisi agar peserta tes dapat dengan mudah memahaminya perangkat tes.

Pada ujicoba tahap pertama, terdapat berbagai kelemahan perangkat tes, seperti istilah teknis dan penulisan kalimat yang dipandang kurang jelas. Ujicoba empiris kedua dianalisis dengan analisis faktor. Analisis ini dilakukan sebagai penegasan (confirmatory) bahwa indikator yang dikembangkan dalam instrumen valid dalam mengukur kompetensi profesional guru. Hasil analisis memenuhi syarat validitas jika jumlah faktor diekstraksi sama dengan jumlah faktor yang mempunyai variansi (eigen value) lebih besar dari 1.0 dan keseluruhan faktor yang memiliki variansi lebih dari 1.0 harus mengukur minimal $60 \%$ dari variansi total. Proses analisis dilakukan melalui seleksi muatan faktor (factor loading) yaitu ekstraksi komponen utama (extracting principal component) dengan rotasi ortogonal untuk memaksimalkan variansi (variance maximizinglvarimax) antar variabel. minimal total varians komulatif sebesar $60 \%$. Hasil ujicoba koefisien reliabilitas tes kompetensi profesional sebesar 0,858. Hal tersebut menunjukkan bahwa tes yang dikembangkan telah memenuhi persyaratan validitas dan reliabilitas.

Hasil analisis tentang skor kompetensi profesional yaitu banyak guru memiliki skor kecil dari 50 dengan rentang 0 sampai 100 . Hal ini bermakna bahwa pada umumnya kompetensi guru perlu dikembangkan, terutama pada kompetensi profesional. Ini berindikasi bahwa, para guru masih kurang mengikuti perkembangan ilmu pada bidangnya terutama bidang teknik bangunan.

\section{Simpulan dan Saran \\ Simpulan}

Berdasarkan tes yang dikembangkan dapat disimpulkan bahwa: 1) kompetensi profesional guru SMK bidang keahlian teknik bangunan di Medan masuk kategori perlu perbaikan; dan 2) kualitas tes yang dikembangkan memiliki karekateriktik baik. Adapun karaktersistik tes yang dikembangkan diuraikan seperti berikut. Uji validitas konstruk teoritis yang menggunakan rational judgement diperoleh nilai median berkisar antara 7,00 sampai 9,00, dengan koefisien interrater sebesar 0,785. Uji empiris tahap pertama diperoleh 17 butir yang tidak valid dengan koefisien reliabilitas sebesar 0,963. Uji empiris tahap kedua diperoleh nilai KMO sebesar 0,780 dan nilai Barlett's test of Sphericity sebesar 12737,796 dengan $\mathrm{db}=1378$ dan signifikansi kecil dari 0,01. Total variance explained dari 10 faktor diperoleh sebesar 0,7078. Hasil rotasi dengan 22 
kali iterasi memperlihatkan semua muatan faktor memiliki nilai diatas 0,30 . Nilai muatan faktor tertinggi (factor loading) 0,804 yaitu butir 27 , dan nilai muatan faktor terkecil butir 32 sebesar 0,303. Pengujian kesesuaian goodness of fit test menghasilkan indeks sebesar 373,123 dengan $\mathrm{db}=190$ dan signifikasi 0,000. Reliabilitas internal yang dihitung dengan rumus KR-20 diperoleh koefisien sebesar 0,858 .

\section{Saran}

Berdasarkan hasil penelitian dapat dikemukakan beberapa saran yaitu: 1) perlu ditingkatkan kompetensi profesional guru SMK bidang keahlian teknik bangunan, agar dapat meningkatkan mutu pendidikan secara umum; dan 2) perlu ditingkatkan kualitas instrumen (tes kompetensi profesional guru SMK) dengan menambah butir-butir pertanyaan yang lebih rinci; menambah responden untuk ujicoba dan dan mengkaji konten profesionalisme guru SMK lebih rinci.

\section{Pustaka Acuan}

Aiken, Lewis R. 1994. Psychological Testing and Assesment. Boston: Allyn and Bacon. Arikunto, Suharsimi. 2002. Prosedur Penelitian, Suatu Pendekatan Praktek. Jakarta: Rineka Cipta. Azwar, Saifuddin. 2003. Reliabilitas dan Validitas. Yogyakarta: Pustaka Pelajar.

Cronbach, Lee J. 1984. Essentials of Psychological Testing. NY: Happer and Row Publ.

Departemen Pendidikan Nasional. 2002. Pengembangan Sistem Pendidikan Tenaga Kependi-dikan Abad ke 21 (SPTK-21). Jakarta: Depdiknas.

Djaali dan Pudji Muljono. 2004. Pengukuran Dalam Bidang Pendidikan. Jakarta: PPs Universitas Negeri Jakarta.

Djamarah, Syaiful B. 2005. Guru dan Anak Didik Dalam Interaksi Edukatif: Suatu Pendekatan Teoritis Psikologis. Jakarta: Rineka Cipta.

Ebel, Robert E. and David A. Frisbie. 1991. Essentials of Educational Measurement. New Jersey: Prentice Hall.

Elliot, Andrew J. and Carlos S. Dweck. 2005. "Competences and Motivation", Handbook of Competence and Motivation, ed. Andrew J. Elliot, and Carlos S. Dweck. New York: The Guilford Press.

Gable, Robert K. 1986. Instrumen Depelopment in The Affective Domain, Boston: Kluwer-Nijhoff Publ.

Gronlund, Norman E. and Robert L. Linn. 1990. Measurement and Evaluation in Teaching. New York: McMillan Inc.,

Hadiyanto, 2004. Mencari Sosok Desentralisasi Manajemen Pendidikan di Indonesia. Jakarta: Rineka Cipta.

Interstate New Teacher Assessment and Support Consorcium (INTASC) Standards, http:// education.bye. edu/INTASC Standards.html

Echols, John M. dan Hassan Shadily. 1997. Kamus Indonesia Inggiris. Jakarta: PT. Gramedia.

Kanfel, Ruth and Phillip L. Ackerman, 2005. "Work Competence: A Person-Oriented Perspective", Handbook of Competence and Motivation, ed. Andrew J. Elliot and Carlos S. Dweck. New York: The Guilford Press,

Litwin, Mark S. 1995. How to Measure Survey Reliability and Validity. London: Sage Publications.

Prayitno. 2005, "Pendekatan Basic Need Dalam Pendidikan: Aplikasi Ilmu Pendidikan" makalah disampaikan pada Pertemuan FIP/JIP seluruh Indonesia di Bukittinggi 12-14 September 2005.

Scriven, Michael. 1981. Evaluations Thesaurus. California: Edgeppress.

Sternberg, Robert J. 2005. "Intelligence, Competence and Expertice", Handbook of Competence and Motivation, ed. Andrew J. Elliot, and Carlos S. Dweck. New York: The Guilford Press,

Sukamto, 2004. Pengembangan Sistem Penilaian Untuk Sertifikasi Guru, makalah disampaikan pada seminar nasional "Rekayasa Sistem Penilaian Dalam Rangka Penilaian Kualitas Pendidikan", Yogyakarta: 26-27 Maret 2004.

Tabachnick, B. G. and L. S. Fidell. 1989. Using Multivariate Statistics. Second Ed. New York: Harper Collins Publ. 